\title{
NOTÍCIAS
}

\section{DEFESAS DE MESTRADO}

\section{Ricardo Vinicius Ibañez Mantovani}

Limites epistemológicos da apologética de Blaise Pascal

Orientador: Prof. Dr. Luís César Guimarães Oliva

Data: 04/12/2014

Resumo:

Os fragmentos que compõem a obra que, hoje, conhecemos como Pensées, são notas preparatórias de uma apologia da religião cristã que Blaise Pascal pretendia escrever. Ao nos debruçarmos sobre as anotações do filósofo francês, chama-nos a atenção o fato de o autor, em nenhum momento, propor qualquer demonstração metafísica da existência de Deus ou mesmo pretender provar, de modo inquestionável, algum dos dogmas católicos. A total ausência de demonstrações que se pretendam perfeitamente probantes explica-se, a nosso ver, pelo fato de Blaise Pascal ser um filósofo cético, ou seja, pelo fato de Pascal não crer que a razão humana é um instrumento capaz de apreender a Verdade. Assim, trata-se, aqui, de, primeiramente, estipular a plausibilidade da hipótese de leitura segundo a qual Pascal pode, com justiça, ser considerado um pensador cético. Isto feito, tratar-se-á de analisar os motivos que levaram nosso filósofo a não se utilizar de nenhuma das tradicionais provas da existência de Deus e a não considerar como plenamente probantes os raciocínios por ele elaborados em prol da religião cristã - fatos que caracterizamos como limites epistemológicos da apologética de Blaise Pascal.

\section{Sacha Zilber Kontic}

Ideia, imagem e representação: Leibniz crítico de Descartes e de Locke Orientadora: Profa. Dra. Tessa Moura Lacerda

Data: $12 / 12 / 2014$

Resumo:

A presente dissertação busca analisar como a concepção de representação é desenvolvida na filosofia de Leibniz tendo como pano de fundo a crítica que o filósofo faz ao modo como Descartes e Locke compreendem o conceito. Tomaremos como ponto de partida a crítica que Leibniz formula ao conceito de ideia tal como ele se encontra em Descartes, e a reformulação do conceito que ele opera a partir da compreensão da ideia como um gênero expressão. A partir dela, podemos compreender em que sentido Leibniz se vale do paradigma imagético da ideia em um sentido completamente diverso de Descartes. Ademais, ele nos permitirá compreender como, aos olhos de Leibniz, as noções de representação em Descartes e Locke se aproximam, por mais que suas concepções sobre a origem das ideias sejam opostas. Pretendemos com isso mostrar que, apesar da doutrina leibniziana da representação estar implicada 
em seu sistema, ela é profundamente marcada pela oposição ao cartesianismo e ao empirismo de Locke.

\section{DEFESAS DE DOUTORADO}

\section{Patricia Nakayama}

Sobre a descrição do ser (estudo sobre ameríndios, Thomas Hobbes e os rebentos de seu estado de natureza)

Orientador: Prof. Dr. Renato Janine Ribeiro

Data: $12 / 08 / 2014$

Resumo:

A presente pesquisa trata da inter-relação entre a enunciação do ser e a política, tanto no Estado Civil, a partir do paradigma hobbesiano, como dentre os ameríndios. Em outras palavras, segue-se em busca das relações entre os sujeitos filosóficos e linguísticos destes enunciados. Para a compreensão desta inter-relação, o estudo parte das fontes antigas que engendram as formas hobbesianas para se concretizar os monopólios das fonte de poder pelo soberano, a saber força e inventio, bem como sua relação com as unidades descritivas das línguas modernas que possibilitam estas formas de monopólio. No caso dos ameríndios, compreender a relação entre a efetivação da democracia grega idealizada ou da cosmodeliberação e as estruturas linguísticas enunciativas que a proporcionam. No Estado Civil, o soberano descreve o ser delimitando sua existência, seus deveres e direitos. Dentre os ameríndios, não há alguém ou alguma instância que descreva de modo monopolizador o que é o ser. A apropriação de palavras alheias aos modos operandi ameríndio também é interesse deste estudo, pois são indícios enunciativos do encontro destes dois modos de conduzir os homens, conformando a relação entre a descrição do ser pelo Estado civil e a descrição polifonica ameríndia sobre o cosmo. 